Article

\title{
Women and Ultramodern Buddhism in Australia
}

\author{
Anna Halafoff *, Jayne Garrod and Laura Gobey
}

School of Humanities and Social Sciences, Deakin University, 221 Burwood Hwy, Burwood, VIC 3125, Australia; jgarrod@deakin.edu.au (J.G.); laura.gobey@deakin.edu.au (L.G.)

* Correspondence: anna.halafoff@deakin.edu.au

Received: 5 April 2018; Accepted: 24 April 2018; Published: 2 May 2018

\begin{abstract}
Buddhists started arriving in Australia in large numbers during the mid-1800s, and the first Buddhist societies and centres began to be formed in the mid-late 1900s. This paper examines the role of women in bringing Buddhism to and establishing it in Australia. Women have featured prominently in a small amount of scholarship, including Paul Croucher's (1989) Buddhism in Australia: 1848-1988 and Cristina Rocha and Michelle Barker's (eds. 2011) edited volume on Buddhism in Australia: Traditions in Change. This paper draws on these sources, but primarily on more recent digital oral histories of prominent Buddhist women and men in Australia, recorded as part of the first stage of the Buddhist Life Stories of Australia project in 2014-2015. These first-hand accounts bring the early female pioneers of Buddhism in Australia to life and provide a rich re-telling of this history with emphasis on women's contributions to it. We also argue that these women's experiences can best be understood through a framework of 'ultramodern Buddhism,' built upon theories of modern and post-modern Buddhism, as many of these women were trailblazers bridging dualisms of tradition and modernity, Asia and the West, and adhering to both feminist and Buddhist principles.
\end{abstract}

Keywords: Buddhism; Australia; women; feminism; modern Buddhism; ultramodernity

\section{Ultramodern Buddhism}

Global flows of Buddhism have resulted in a vast diversity of Buddhist lineages and communities settling in Australia since the mid-1800s (Barker and Rocha 2011). As a result of this long and rich history, Australia's relative isolation and small population, and the establishment of Buddhist Councils bringing these diverse communities and traditions together, the divisions between ethnic/Asian immigrants and Anglo-European/Western converts are not as strong in Australia as in other Western societies. Other key themes emerging from recent research on Buddhism in Australia also include an emphasis on scientific rationalism, a strong connection with the Australian landscape, and an emphasis on gender equality (Halafoff et al. 2012; Ng and Halafoff). This article focuses on the latter theme and argues that not only have women played a prominent role in the history and establishment of Buddhism in Australia, but that the way they have done so can best be understood through a framework of 'ultramodern Buddhism,' building upon theories of modern and post-modern Buddhism, ultramodernity and cosmopolitanism (Halafoff and Rajkobal 2015).

McMahan (2011, p. 160) has described Buddhist modernism as 'a hybrid religious and cultural form that combines selected elements of Buddhism with the major Western discourses and practices of modernity.' McMahan also stated that Buddhism has been 'shaped by an engagement with the dominant cultural and intellectual forces of modernity, such as the European Enlightenment, scientific rationalism, Romanticism and its successors, Protestantism, psychology, and modern social and political thought.' Reformers from Asia were the first to develop a distinctly modern reinterpretation of Buddhism, including Anagarika Dharmapala, D.T. Suzuki, and the 14th Dalai Lama (Lopez 2002; McMahan 2011). This appealed to the founders of the Theosophical Society (TS) who were also 
influential in spreading Buddhism to the West (McMahan 2011). According to Lopez (2002, p. ix), Modern Buddhism 'stresses quality over hierarchy, the universal over the local, and often exalts the individual above the community.' It is practiced mainly by 'cosmopolitan' educated middle classes, with gender equality as a central principle and meditation, as opposed to ritual, as a central practice. It is also equated with a scientific world-view, de-emphasising superstitions, social and political engagement, democracy, and egalitarianism (McMahan 2011).

McMahan (2011, p. 173) himself warns that 'we should be cautious about defining Buddhist modernism too narrowly or about positing a fixed distinction between modernity and "tradition."' Indeed, Quli (2008) study of Theravada Buddhism in the USA, found both traditional and modern elements to be present concurrently. Baumann (2001, pp. 4-5) has argued that a 'post-modernist,' 'global Buddhism' better explains contemporary Buddhism at the turn of the 21st Century, that is 'characterized by more intense transnational and trans-continental flows of Buddhist ideas and practices, disseminated by the global travels of Buddhist teachers and pupils.' According to Baumann, global Buddhism, acknowledges the 'interconnectedness of East and West' and post-modern qualities of 'plurality, hybridity, ambivalence, globality and de-territoriality.'

Michelle Barker and Cristina Rocha (Barker and Rocha 2011, pp. 2, 15) applied Baumann's global Buddhism framework to their study of Buddhism in the Australian context arguing that 'the development of Buddhism in Australia does not happen in a vacuum, but is part of an intense flow of ideas, teachers, students, practices and material cultures between Australia and other countries.' They also noted, citing Spuler (2000) (in Barker and Rocha 2011, p. 11) that Buddhism in Australian included common characteristics of modern Buddhism in Western societies, namely:

... a diversity of traditions and lineages, a differentiation between ethnic and convert Buddhism, an emphasis on lay practice, on the application of democratic principles (exemplified by the existence of elected councils), some emphasis on social engagement, and some emphasis on secularization.

They also added an additional Australian quality of anti-authoritarianism (Barker and Rocha 2011).

Building upon these and other sociological theories, Anna Halafoff and Praveena Rajkobal (Halafoff and Rajkobal 2015) developed a new framework of 'ultramodern Buddhism' while analysing the global Buddhist women's social movement, Sakyadhita. As Willaime (2006, pp. 78-79) stated 'we are actually in a stage of radicalisation of modernity,' as we are increasingly using modern rational and deliberative means to reflexively critique modernity and its inability to deliver economic benefits and equal rights to all. While secular ideals of modernity marginalised and criticised religion, they were de-absolutised in the second half of the 20th century. This led to a revitalisation of religion and spirituality, as people sought alternative meaning systems of how best to live well with one another and the lifeworld (Habermas 1981; Casanova 1994; Beckford 1990; Willaime 2006). Many turned to Buddhism, in both traditional and modern forms, drawn to it for its radical reflexivity, emphasis on the mind and rational thought, as well as principles of interconnectedness and respect for all beings. As Beck (2006, p. 14) argued in his cosmopolitan theory, the ability to transcend modern dualisms and to move away from modern binaries of 'either/or' frameworks toward a 'both/and logic of inclusive differentiation' is a quality of our current era, where 'the old differentiations between internal and external, national and international, us and them' have lost their validity in an increasingly globalised and interconnected world. Therefore, Halafoff and Rajkobal (2015, p. 120) concluded, in their case study of Sakyadhita, that 'in ultramodernity, the traditional and modern are intertwined ... old divisions between Western and Asian Buddhists, lay people and Sangha (monastic orders), scholars and practitioners are becoming increasingly blurred and outdated, as alliances form across spaces in response to common concerns,' in this case particularly of advancing gender equality, drawing on reflexively critical Buddhist and feminist principles. We have observed some similar patterns in our current study of women in Buddhism in Australia, discussed in more detail below.

In addition, our analysis of new data, gathered from digital oral histories of the Buddhist Life Stories of Australia research project in 2014-2015, has also shown a clear pattern of intensification 
of modern Buddhist characteristics from the 1970s onward, as set out by McMahan and by Barker and Rocha in the Australian context, including an emphasis on gender equality, democratisation, rationalism, and meditation. Buddhist women in Australia, during the modern and ultramodern eras have and continue to play a central role in shaping this pattern, as examined in more detail below, thereby further strengthening the case for the applicability of an ultramodern, as opposed to simply a modern or post-modern Buddhist theoretical framework in this paper, and to Buddhism in Australia more broadly.

\section{Buddhist Life Stories of Australia Aims and Methods}

Croucher (1989) definitive text, Buddhism in Australia: 1848-1988 includes colourful descriptions of the many women who helped establish Buddhism in Australia, dating back to the 1880s. Eleven years later, Adam (2000) published a very short article on 'Buddhist Women in Australia,' in the Journal of Global Buddhism, with few citations other than Croucher's text. More recently, Rocha and Barker (2011) edited volume on Buddhism in Australia: Traditions in Change included several chapters pertaining to issues of gender and Buddhism. Since then the Buddhist Life Stories of Australia (BLIA) project, initiated by Halafoff and Edwin Ng at Deakin University in 2015 ${ }^{1}$, has recorded digital oral histories of seventeen highly-regarded Australian Buddhist community leaders, including six Buddhist women (BLSA Buddhist Life Stories of Australia; Ng and Halafoff). These women are: Bhikkhuni Chi Kwang Sunim, an Australian Korean Bhikkhuni; Bhikkhuni Nirodha, an Australian Thai bhikkhuni; Venerable Yeshe Khadro, Venerable Margaret McAndrew, and Venerable Robina Courtin, all Australian Tibetan nuns; and Kathy Vichta, an Australian lay Tibetan Buddhist community leader.

The primary aim of the BLSA Project, developed in consultation with the Federation of Buddhist Councils (FABC) and the Australian Sangha Association (ASA) ${ }^{2}$, was to record the oral histories of prominent Buddhists in Australia, given that some of the esteemed leaders who had arrived in Australia in the 1970s and 1980s, had recently passed away, including Vietnamese Most Venerable Thich Phuoc Hue in January 2012, and Geshe Acharya Thubten Loden, in August 2011. Phra Khantipalo (Laurence Mills) was also suffering dementia and under the care of the Victorian Buddhist communities at that time. This created an urgency to record the life stories of Buddhists in Australia who could still recall its early history.

The BLSA project is interpretive, as it aims to generate a greater understanding of global flows of Buddhists in and out of Australia and is the first stage of a broader project to provide a comprehensive and updated history of Buddhism in Australia. The BLSA study employs both in-depth, semi-structured interviewing and narrative research methods, allowing the Buddhist leaders to tell their own stories and to identify themes and issues that are most important to them, and for the researchers to discover patterns of both individual and social change (Bouma and Ling 2005; Squire et al. 2008). One of the main themes raised by the leaders in this first round of BLSA interviews was gender and Buddhism.

This paper draws on previously published material and primarily the BLSA narratives of the six women named above, and also of five men interviewed for the BLSA project who discussed the prominent role of Buddhist women in Australia in some detail. They are: Graeme Lyall and Michael Wells, both Australian lay Buddhist community leaders; and Phra Rajsilaporn, Ajahn Brahm, and Bhante Sujato, all senior Australian Thai monks.

1 A detailed account of the BLSA Project's conceptualisation, crowdfunding strategy, methods and emerging themes are contained in: (Ng and Halafoff). Buddhist Life Stories of Australia: Crowdfunded Research, Faithful Scholarship, and Inquiries on Making Refuge. Journal of Global Buddhism. under review.

2 The FABC and the ASA are the overarching national Buddhist bodies of Australia. The FABC includes representatives from all of the state Buddhist Councils and is mostly made up of lay Buddhists, while the ASA includes ordained Sangha representatives. 
We focus here largely on the period between the 1880s to the 1990s and thereby on Anglo-European, Western Buddhist women due to the availability of data on this subject, which has thus far been somewhat limited. This is something we hope to address in coming years. We do note that there are highly significant stories of Indigenous women and women from Asia who were/are Buddhist or who had/have a strong interest in Buddhism in Australia, particularly preceding the introduction of the Immigration Restriction Act 1901 and after it was lifted from the 1970s up to our current day, that are yet to be uncovered, recorded, and analysed. The BLSA project had very limited resources, namely $\$ 10,000$ raised from crowdfunding, and also a strict mandate, developed in consultation with the FABC and the ASA, to record the oral histories of those Buddhist Australians who could still recount events from the 1950s onward. As the beginnings of organised convert or Western Buddhism in Australia took place during the time of so-called White Australia Policy, most of the main actors in this part of the story are white. The broader story, beyond the scope of this paper, is far greater and we hope to be able to document it in detail in the near future.

Our analysis of literature on Buddhism in Australia and the newer BLSA narratives demonstrates that from the 1880s to the 1990s women have played a significant part in bringing Buddhism to and establishing Buddhism in Australia, by purchasing land for and establishing Buddhist centres, creating and holding leadership roles in Buddhist Societies, and becoming highly respected Buddhist teachers in and beyond Australia. They have done so in partnership with notable Buddhist lay and ordained men, and our analysis shows that women in most cases feature as prominently as men during this period of the history of Buddhism in Australia, except for in the founding of the Buddhist Society of Victoria in which men dominated initially, as discussed in more detail below.

\section{Buddhist Women's Life Stories in Australia}

Women have been described as having played 'an undersung role in processes of religious settlement' in multicultural and multifaith Australia (Bouma and Brace-Govan 2000, p. 159). While this may be the case for most Australian religious communities, women have featured notably in a comparatively small amount of scholarly material published on Buddhism in this country. This is a somewhat surprising finding given that gender inequalities continue to persist in Buddhist institutions and communities globally (Tsomo 2009). This may be as a result of when the history of Buddhism in Australia was first documented in the late 1980s, when and how Buddhism first came to and became organised in Australia, and also due to the fact that many of the women involved in Buddhism in this country from this early modern period have had very strong characters and have been highly committed to feminist causes.

Gross (2005) has stated that women were rarely the focus of scholarship on religion before the 1960s, and that significant progress has been made since then, although addressing gender inequalities within religions remains an ongoing project. Tsomo (2009, pp. 152-53) has also observed how 'Buddhist women's leadership and contributions,' to maintaining centres, translating, fundraising, welfare, and teaching, 'are becoming increasingly prominent' and valued, in both Asian and Western societies, as over 'the past twenty years in all of these Buddhist communities, a trend toward greater visibility, independence, recognition, and equity for women has begun to emerge.'

Croucher's Buddhism in Australia was published in 1989, and he dedicated substantial sections throughout his text to Buddhism women in Australia. Subsequent studies listed above have similarly sought to be inclusive of and to highlight women's roles in and perspectives on Buddhism in Australia, and this practice continues to this day, as evident in the BLSA project. Although it should be noted that this BLSA website currently hosts only six video interviews with women out of a total of seventeen. This disparity will be addressed in future.

\section{Early Contact and Early Immigrant Buddhism}

The periods of 'early contact' and 'early immigrant Buddhism' (McAra et al.) include interaction between Indigenous people of Australia and Buddhists from Asia, including Gujarati seamen with 
trade links with Java, Ming-dynasty maritime explorers, and Japanese samurai, and later waves of Chinese communities on the goldfields, Singhalese Buddhists employed in the Queensland sugar-cane industry, and Japanese and Sinhalese Buddhist immigrants in the northern Australian pearling industry in the 19th century (Croucher 1989). Croucher (1989) briefly described them and there is no mention therefore of particular women during these times except for of a statue of Kuan Yin, in the South Melbourne Temple dating back to 1883. More research needs to be conducted in order to uncover the stories of the first Buddhist women in Australia and of Buddhism in the Far North, where much of this first contact occurred.

The Immigration Restriction Act 1901 resulted in a dramatic decline in the number of ethnic/immigrant Buddhists in Australia until the 1970s. This period was thereby dominated by Western converts to, and/or students/practitioners of Buddhism, many of whom were women. Croucher (1989, pp. 7-10) describes how Emma Harding Britten, an American Theosophist toured Australia in 1878 and how branches of the TS were established in Tasmania in 1889 and in Melbourne in 1890. The founder of the Melbourne branch was a Russian woman, Elise Pickett, who was described as the first "White Buddhist" to have set foot on Australian shores.' TS co-founders Madame H.P. Blavatsky (1831-1891) and Colonel Henry Steel Olcott (1832-1907), the latter who toured Australia lecturing on Theosophy and on Buddhism in 1891 and in 1897, were also 'great trail-blazers for Buddhism,' stating that 'it is only in the context of their efforts that the history of Buddhism in Australia can be understood.' These modern Theosophist Buddhist women strengthened ties between Asia and Oceania and initiated a pattern of gender equality in Australian Buddhism, in which women have long played a central role.

\section{Early Western Buddhists}

It wasn't until about 40 years later that the first Buddhist Study Group formed in Melbourne, Victoria. The first Buddhist Societies of New South Wales and Victoria were formed in Sydney and Melbourne soon after in the early 1950s. Croucher (1989) describes this period as the beginning of organised Buddhism in Australia.

Marie Byles (1900-1979) was 'the first woman to graduate in law in New South Wales ... a pioneer conservationist, mountaineer, bushwalker, pacifist, feminist and Buddhist' with 'Theravadin leanings' (Croucher 1989, pp. 32-34). Graeme Lyall (1931-2015), one of the central figures of Buddhism in Australia in the 20th Century who worked tirelessly to establish Buddhism, and to assist ethnic Buddhist communities to settle and practice Buddhism in this country, recalled how, 'she did a lot for the establishment of Buddhism' in Australia (Lyall 2014). Byles had travelled widely through Asia and amassed a vast collection of Buddhist texts and books, including the complete Pali Canon. She also wrote several books on Buddhism, including Footsteps of Guatama the Buddha, and Voyage into Burmese Silence, which was about meditation. Lyall (2014) also stated that Byles was a 'staunch feminist' and that she actually 'didn't like organised Buddhism, so she never actually became a member of the Buddhist Society. She attended the meetings but didn't actually become a member.' She practiced mainly family law and it was suspected that it was one of her client's husbands who was responsible for the horrific attack on her in her home, which led to her becoming 'more or less a recluse' afterwards until the time of her death.

Croucher (1989) and Lyall (2014) both described how Leo Berkeley was born in Holland and came to Australia in 1947. Berkeley was a businessman who had first become interested in Buddhism on a business trip to the UK, around 1950, where he befriended a Sri Lankan dignitary who then introduced him to the famous Sri Lankan Theravada monk Narada Maha Thera in Colombo, when their ship stopped there. It was Narada Maha Thera who then suggested that Berkeley should form a Buddhist group, when he returned to Australia. The only person Berkeley could think of contacting who knew anything about Buddhism at the time was Marie Byles, who replied, 'Oh, Mr Berkeley, Australians aren't yet ready for Buddhism.' To which he responded, 'if you are ready, and I am ready then together we can form an Association' (Lyall 2014). 
Soon after, Sister Dhammadinna (1881-1968), a somewhat controversial figure first visited Australia in 1952 (Croucher 1989; Lyall 2014). Lyall (2014) noted that Dhammadinna's life story was 'shrouded in mystery,' and that 'there were several rumours,' 'all unconfirmed' but that 'supposedly she was the wife of a General of the Russian Tsar.' She was reportedly educated at the Sorbonne University, which Lyall believed to be true given her cultured and intelligent manner. She was also rumoured to be part of the Standard Oil company family from the US. Previous to her visiting Australia, Dhammadinna had lived in Sri Lanka in a Forest Hermitage, which Lyall (2014) said was later given to the famous German Buddhist monk Nyanaponika Thera, and G.P. Malalasakera, the founder of the World Buddhist Fellowship, was believed to have paid Dhammadinna's fare to Australia. Lyall (2014) also described her as Theravada, with Mahayana leanings.

Lyall (2014) recalled how as a young man when he first became interested in Buddhism, after meeting fellow university students from Sri Lanka who were in Australia as part of the Colombo Plan, he contacted the TS in Sydney and they advised him that there was an elderly Buddhist nun teaching at the home of Leo and Lummechien Berkeley. Lyall (2014) recounted how when Dhammadinna first arrived she had 'one address and about 10 pounds, and that address was of Marie Byle's ... home in Cheltenham.' When she arrived Byles 'ushered her to an open shed, which she called "the Hut of Happy Omen" and told Dhammadinna, "right, you can stay there".' Dhammadinna at that time was 84 and wore a back-brace as a result of a fall, 'so the "Happy Omen" was less than happy' for her. Berkeley instead found Dhammadinna a flat to live in in Sydney's Eastern suburbs, that she shared with several other women. She was a strict vegetarian and Lyall (2014) remembered how at one time when they were cooking a Sunday roast she walked by and asked, 'do I smell a corpse in here?' She was, in Lyall's words, 'quite a formidable lady' and did not have many students. He also commented that she was 'quite notorious' for trying to turn spouses against one another, 'as she wanted everybody to be celibate. She taught at the Berkeley's, the TS, and the Centre Club in George St. Lyall (2014) described his first meeting with Dhammadinna as follows:

I was sitting in this room when a strange apparition appeared, a woman with no hair, wearing a yellow robe. I'd never seen anything like that before in my life! And the first thing she did was say, which is Mr Lyall? So I indicated it was me and she said "well if you can't sit properly, get out of the room." And after she gave her dharma talk she called me over and she said, "you passed my test, if you'd been insulted you'd make no progress in Buddhism! I accept you as a student." So that was my introduction, getting hit over the head by a sledge hammer. (Lyall 2014)

But he added that,

I had a lot of respect for her, and she was a good teacher. She taught us chanting and we would study sutras ... she was quite a thorough teacher. A little bit mixed up ... but good, I'm very grateful to her. (Lyall 2014)

Lyall and seven others took refuge with Dhammadinna, on Vesak Day in 1953 at the Berkeley's house, and soon after this group formed the Buddhist Society of New South Wales (BSNSW). Berkeley was President and Lyall was Secretary. Byles, and the Japanese and Burmese Ambassadors were also present at that first official Vesak celebration in Australia and Lyall (2014) remarked how these 'diplomats were very interested in seeing ... the blossoming of Australian Buddhism.'

After her initial year in Australia, Dhammadinna returned four years later in 1957 to conduct a retreat at Eric and Lyn Penrose's property in the Northern Beaches. They built a 'granny flat' for her but their application to extend her visa was unsuccessful and she left for Hawaii in 1958 and died there in 1968 (Croucher 1989, p. 42; Lyall 2014).

Dhammadinna had a profound influence on Natasha Jackson, who described Dhammadinna as the 'Founder of Australian Buddhism,' a title that Croucher (1989, pp. 36-41) felt she did not really deserve, yet Lyall's account above indicates that she did play a central role as the first visiting dharma 
teacher in Australia. The BSNSW, under the leadership of Berkeley and Byles concentrated on hosting qualified teachers and meditation sessions and retreats. It began producing the Buddhist News in 1953, which was renamed Metta in 1955. The Buddhist Society of Victoria, was formed in 1953, and a national body, the Buddhist Federation of Australia was founded in 1960, with Metta becoming a national journal at that time also (Croucher 1989). Elizabeth Bell (1911-2007) joined the BSV in the early 1960s and hosted regular meetings at her North Carlton home (Croucher 1989). Bell went on the play a significant role in Buddhism in Victoria from the 1970s onward, described in more detail in the 'Buddhist Boom' section below.

Natasha Jackson (1902-1990) took over from Berkeley and ran the BSNSW, and edited Metta from 1956 to 1971 (Croucher 1989). Jackson was a Russian immigrant, and member of the Communist Party (Lyall 2014). She marched in anti-war protests and also campaigned for Aboriginal land rights in the 1960s, reflecting her commitment to a socially engaged Buddhism (Croucher 1989). Lyall (2014) described the BSNSW under her leadership as 'armchair Buddhism,' and explained how they would debate Buddhist concepts such as karma and rebirth, but 'that there was no practice whatsoever, meditation was definitely out and it was more or less Buddhist theory.' Lyall (2014) also noted how Jackson really 'didn't like monks' and had made it very difficult for the first Buddhist monk that the BCNSW sponsored to live in Australia. As a result, he only stayed for around 12 months. She did however play a central role in bringing more Thai monks to Australia in the early 70s, and they remain very grateful to her for that (Rajsilaporn 2015).

This period from the 1950s to the 1970s can be seen as a bridge between modern and ultramodern periods. Women such as Byles and Jackson were also trailblazers of Buddhism in Australia, in vastly different ways. Byles was interested in traditional Buddhist texts and meditation practices and was a strong feminist and socially engaged Buddhist who had little interest in organised Buddhism. Jackson was interested in Buddhist theory, not practice, and was also socially engaged, and led the BSNSW for 15 years. Their involvement in Buddhism in Australia further illustrates the central role that women played in the establishment of Buddhism in this country and can be seen to have paved the way for an ultramodern approach to Buddhism that developed more strongly from the 1970s onward.

\section{The Buddhist Boom}

In the 1970s, and after the end of the White Australia Policy, large flows of Buddhists from Asia began settling and erecting temples in Australia of Thai, Vietnamese, Chinese, Singhalese, Cambodian, Burmese, Laotian and Tibetan traditions (Croucher 1989). Adam (2000, p. 139) observed that until the 1970s Buddhism in Australia had depended largely upon lay people, and that this enabled women to play a central role. However, the 1970s heralded a 'new time of male leadership' given that resident monks and teachers could stay in Australia and establish monasteries and temples. There were however some notable exceptions, as Buddhist women from a number of traditions, played a significant part in establishing centres and associations, and became internationally recognised teachers in their own right. As noted above, this paper focuses mainly on Anglo-European, Western Buddhist women during the early period of the Buddhist Boom as further research needs to be conducted on the contributions made by Buddhist women from Asia to Australia from the 1970s onward.

In 1973, two monks from Thailand arrived in Sydney, sponsored by the BSNSW. One of them was an English Thai monk Phra Khantipalo. They lived in a rented house and then moved to a beautiful property bought by the Thai Government in Stanmore, which they called Wat Buddharangsee, that opened on Vesak Day in 1975. In the late 1980s the Thai Buddhists also established a Centre called Wat Pa Buddharangsee, at Lumeah, whose current Chief Abbot, Phra Rajsilaporn (Chao Khun Samai), arrived in Australia in 1974 (Rajsilaporn 2015). Khantipalo and Rajsilaporn both subsequently became leading figures in Buddhism in Australia (Croucher 1989; Lyall 2014).

Rajsilaporn (2015) explained how they were the first resident monks to live and stay in Australia, so in those early days many nationalities of Buddhists from Asia, including Thais, Burmese, Sri Lankans, Vietnamese, Cambodians, and Laotians and Australians interested in Buddhism would 'come to us.' 
He said that from the 1970s to the early 1980s Khantipalo was 'very popular' and that 'hundreds of people attended his talks' and that they were 'mostly Australian' but also from Asian diaspora communities. Rajsilaporn (2015) stated: 'In those days, there was no competition, he was the one ... he has done a great deal ... before anyone else ... his knowledge in Buddhism is great.'

One of Khantipalo's first students, was German born Ilse Ledermann (1923-1997), who later ordained in Sri Lanka in 1979 and became Ayya Khema, a highly-respected teacher of Buddhism internationally (Lyall 2014). Lyall (2014) recalled how she was 'not a very friendly woman' and how he had invited her to give a dharma talk after which he had said 'thank you Sister,' to which she had gruffly replied 'don't call me Sister, you make me sound like a nurse!' By contrast, Rajsilaporn (2015) said that both Khantipalo and Ledermann had been very kind to him and 'had done a lot [for establishing Buddhism in Australia], they sacrificed their whole life for the happiness of others for so long.'

Australian Venerable Chi Kwang Sunim, formerly Debbie Cain, was one of Khantipalo's and Ledermann's first serious students, who later trained and ordained in Korea and lived there for 20 years before returning to Australia. Her home temple was Songgwangsa and she still retains strong connections with Korea and usually visits there every two years (Croucher 1989; Sunim 2015). As a well-respected teacher, she remains another central figure in Buddhism in Australia.

Sunim was born and grew up in Western Australia, until she moved to Sydney at the age of 24. She had been practicing yoga for years but first heard about Buddhism and meditation whilst studying art at university. In the mid-1970s, she participated in a Vipassana retreat led by visiting teacher John Colemen, a student of Sayagyi U Ba Khin. She stated that: 'I was very inspired from my experience, still knew little about Buddhism but I think the actual experience of meditation was well founded in that short time.' She returned to Western Australia, to teach at the Art Institute in Freemantle, and searched for more Buddhist teachers in Western Australia, but there weren't any there back then. She heard that Khantipalo was leading retreats in Northern New South Wales, so she returned to the East to participate in a one-month retreat led by Khantipalo and Ledermann around 1976-1977 (Sunim 2015). Sunim described how

... it was a lovely retreat because he was rather stern and very strict with his ... monastic protocol and she was very loving and very warm-hearted. So I sat with them for a month, there was three 10-day retreats and it was a very impressionable retreat for many people.

(Sunim 2015)

Of the small group that attended this retreat, five were ordained, and many devoted the rest of their lives to Buddhism including Subhana Barzaghi, another well-respected Australian Buddhist teacher, in the Zen tradition (Sunim 2015). ${ }^{3}$

Sunim (2015) described Ledermann as a 'very complex person' who, as a young Jewish German girl, had escaped to England during the Second World War. She was later reunited with her parents in China and married an older man with whom she had two children. She then travelled with her second husband to Australia and both developed an interest in Buddhism. They also participated in Vipassana retreats, led by Robert Hover and Coleman, and that was how Ledermann first met Khantipalo. Sunim said Ledermann 'was very, very strong and clear minded so when she put words together they hit people in such a way that you didn't forget them.' She also added that Ledermann's 'emotional relationship with Khantipalo was a little fraught, they didn't see eye-to-eye on many issues but I think in many ways he was still her teacher' and that 'she was an inspiration to me too and others who came.'

Sunim (2015) described how following that first one-month retreat she participated in they lived for six months at Wat Buddharangsee, and that she was 'more a friend to Ilse and a student to

3 The BLSA Project has not yet interviewed Subhana Barzaghi but hopes to do so in the near future. Her story is included in (Barker and Rocha 2011, pp. 124-33). 
Khantipalo [and an] attendant to both and was very much a part of helping' them establish their Centre Wat Buddha Dhamma north of Sydney, near Wisemans Ferry. Sunim recalled how,

Khantipalo had seen a beautiful property in the Dharug National Park ... and he had a great interest to purchase this property. Ilse was the benefactor, she was the person who had come through a difficult separation with her husband and she was selling her farm which I helped her, helped her to do and then that funded this property and it was a very large property ... and it had some dwellings on it. So after about six months ... at Wat Buddharangsee ... we moved together onto this property. (Sunim 2015)

The property needed 'a lot of work' and 'every weekend there were a lot of people who came to help.' Khantipalo had been leading retreats at Ledermann's and her former husband's property and had also been teaching at two Buddhist 'hippy' communities in northern New South Wales at Boddhi Farm and Dharmananda, so they had quite a following to assist them. Sunim herself lived in 'a little cave' that she had put a floor in, which became known as 'Debbie's cave,' her name at that time. She lived at Wat Buddha Dhamma until 1979, when, following Khantipalo's advice, she travelled to Korea to train and ordain as a bhikkhuni, as she had had a dream she would become a nun. She recalled how Khantipalo 'could see that Thailand would be difficult' and inspired her to go to Korea as he knew from correspondence with fellow monks that 'the nuns in Korea were very good and very developed, [and that] they were the bhikkhuni who had a good education and were respected by the monks' (Sunim 2015).

Ledermann/Khema was highly influential in establishing the Buddhist women's social movement Sakyadhita, in 1987, together with the American Tibetan nun Karma Lekshe Tsomo and the Thai professor Chatsumarn Kabilsingh, who later took full ordination as is now known as Bhikkhuni Dhammananda (Sakyadhita n.d.). Sakyadhita has tirelessly campaigned for gender equality in Buddhism and for bhikkhuni ordination globally. Both Khema and Sunim participated in the 1989 bhikkhuni ordination that took place in Los Angeles led by Taiwanese Fo Guang Shan bhikkhuni in the Mahayana tradition, and supported by Sri Lankan and Korean bhikkhuni (Sunim 2015).

When Sunim returned to Australia, she first met Lyall, who introduced her to many monastics who had by then established temples in Thai, Cambodian, Sri Lankan, Chinese and Tibetan traditions. Together with Khantipalo, they created a Buddhist library in partnership with the newly arrived Buddhist communities. Sunim initially connected with a Korean community in Sydney, and then another in Melbourne. She raised money to buy land at Daylesford in 1997. While raising funds to build the Temple there, she established another Centre in Hepburn Springs, which was extremely popular and then moved to the Daylesford property. Planning permits and the distance from the Melbourne CBD led her to move to and build another Temple in Kinglake, although Buddhism is still flourishing in the Daylesford area (Sunim 2015).

Sunim was also active in the Buddhist Councils of New South Wales and remains active in the Buddhist Council of Victoria and also in the FABC and the ASA, founded in the mid-2000s. Not only have the FABC and the ASA supported both lay and ordained Buddhists and so-called Western and Asian Buddhists in Australia and significantly bridged gaps between them, but the ASA in particular has since its inception been committed to gender equality (Sunim 2015). As Sunim explained,

And one of the major issues was that of bhikkhuni, to support the ordination and the development of education for Buddhist women to the highest levels to become bhikkhuni. And now many of us came out of a bhikkhuni tradition such as the Taiwanese nuns, the Fo Guang Shan nuns and various Chinese and Vietnamese nuns but still there were many in robes in Australia, particularly the Tibetan nuns and the Theravada nuns who did not have the opportunity to take full ordination. So we thought at least it is important for us to address what are the problems, what are the concerns with traditional monastics and to see if we could find ways to further the great benefits of women becoming fully ordained. (Sunim 2015) 
She also added that,

... most of the monks who live abroad or the younger ordained monks are very supportive because you can see the value, the value of women in any society where women become educated, have the opportunity to go to school, become educated, it supports the society ... anyone who has been ordained as a bhikkhuni knows there is a difference, just through maybe the understanding of what it is to wear robes with the full integrity of being you know a fully ordained nun, holds a lot of power just as it does for monks. And we're now in a world where the separation and segregation, you know the identity between men and women is lessening, you know so many cultures now women have equal opportunities or the gap is closing, [although] still not fully ... (Sunim 2015)

Ayya Nirodha Bhikkhuni, another prominent Australian Buddhist woman, first met Khantipalo and Ledermann in 1979 at a retreat they led at Wat Buddha Dhamma (Nirodha 2015). She recounted how,

[Ledermann] ordered me to sit right in front of her. And, for whatever reason, I don't know why, the was one of the first few times in my life that I actually followed instructions, because I'm a very independent spirit ... But somehow, I fell in and for me it was a very powerful retreat. And ... from then on of course, I saw life in a little bit different way. I could understand myself deeper, and I would say that was the beginning of many, many, changes. (Nirodha 2015)

Born Elisabeth Gorski in Austria at the end of the Second World War, she grew up in the outskirts of Linz, and emigrated to Australia at age 20 with her former husband. Divorcing and remarrying a few years later, she experienced a privileged life of a Sydney socialite, travelling often to Europe and residing in prestigious Darling Point. Following her second divorce she attended a health retreat in the Blue Mountains 'out of boredom,' where the biggest decision she had to make was whether to play tennis or cards, and it was here she began to question the shallowness of her current lifestyle, and to look for deeper purpose (Nirodha 2015).

One of her neighbours introduced her to a visiting Indian Guru and also told her about Wat Buddha Dhamma. After the first retreat, she attended many more and described feeling 'very much at home with the Buddhist teaching' and meditation. She also noted how her Buddhist study and practice enabled her to understand her 'Christian roots' much better. Nirodha was also initially involved with the Insight Meditation Society in the Blue Mountains that hosted visiting teachers, such as Joseph Goldstein, following which she spent time in Buddhist centres in both the US, and in Burma (Nirodha 2015).

In 1986, Nirodha purchased a property in Bundanoon NSW, to establish a meditation centre. After her partner passed away she had a strong aspiration to become a nun, and then offered the property to Ajahn Brahm, a well-known monk and highly respected teacher in the Thai Forest tradition Ajahn Chah lineage (Nirodha 2015). Brahm established Bodhinyana Monastery, for Thai Forest monks in the early 1990s and Dhammasara Monastery, for Thai Forest nuns in 1998; both are an hour out of Perth in Serpentine and Gidgegannup respectively. Ajahn Vayama, another student of Khema's, was the first Abbess of Dhammasara and lived in a caravan in tough conditions before any buildings were erected. According to Brahm, she was 'a pioneer' who really 'got [Dhammasara] started,' although this took a significant toll on her health (Brahm 2015). Nirodha regularly travelled to Perth to attend Brahm's retreats and in 2001 she also moved to Dhammasara. In 2003, she was the first sramaneri, 10 precept nun in the Thai Forest tradition to be ordained in Australia (Nirodha 2015). In 2003, the Bundanoon property became Santi Monastery, a Centre for Thai Forest nuns under the leadership of Bhante Sujato. Both Brahm and Sujato have long been strong advocates for gender equality in Buddhism, and Sujato is a well-respected figure, particularly given his scholarly expertise and digital activism through 'Sujato's blog' (Nirodha 2015; Sujato 2015).

Nirodha first discovered the cave at Santi, which Sujato later excavated. He stayed on as Abbott at Santi until 2012, when he returned to Bodhinyana. Since that time, Nirodha has been the Abbess 
(Nirodha 2015; Sujato 2015). Four nuns from the Dhammasara nun's community, including Vayama and Nirodha, requested to become bhikkhunis in 2009. The Bodhinyana Sangha and lay community discussed the proposal in detail and eventually agreed that the nun's request be granted, so Brahm performed the bhikkhuni ordination on the 22 October 2009 (Brahm 2015; Sujato 2009). A subsequent bhikkhuni ceremony was conducted at in the Santi Cave on 4 September 2016, with both Nirodha and Sunim present. The ordination was confirmed at Bodhinyana Monastery on 22 September 2016 (Santi Forest Monastery 2016a, 2016b). It is also of interest to note that the Thai Forest Monasteries are not only pro-gender equality but also welcome a large number of diverse Buddhist communities including Thai, Sri Lankan, Cambodian, Vietnamese, and Malaysian Chinese, as well as Westerners (Nirodha 2015). These bhikkhuni ordinations have generated a significant amount of controversy as they have been opposed by the Thai Forest tradition in Thailand (Brahm 2009; Sujato 2009; Halafoff and Tomalin 2017).

Women have also played an important role in establishing Tibetan Buddhism in Australia. Dr Nicholas Ribush and Marie Obst (now an ordained nun known as Yeshe Khadro) were among the first Australians to meet Lama Thubten Yeshe and Lama Thubten Zopa Rinpoche in Nepal in 1972. They were the first Tibetan Lamas to visit and establish centres in Australia (Khadro 2015). Lama Yeshe passed away in 1984, and Lama Zopa remains the Spiritual Director of their organisation, the Foundation for the Preservation of the Mahayana Tradition (FPMT), and still regularly teaches in Australia.

Marie Obst was born on a farm out of Brisbane and was brought up in a Catholic family and later a boarding school in Ipswich. She trained and worked as a nurse in Brisbane, where she met Ribush. Ribush was interested in meditation and Buddhism, and initially Khadro 'just went along' travelling with him as they were in a relationship together. They journeyed though South East Asia to Nepal, where they had heard from other travelers about the Lama's one-month meditation courses at Kopan Monastery in Kathmandu. They enrolled in the Lama's third course and Khadro recalled how 'the amazing thing that turned my life around was that so many things in that course, the beliefs I had grown up with and been taught, there was a logical explanation given in the Buddhist context ... so it totally rejuvenated my religious, spiritual practice.' She was also interested in the many similarities between Buddhism and Catholicism. She took refuge at the end of that course in 1972, and was given the name Yeshe Khadro by Lama Yeshe. They stayed on in Kopan in 1973 and invited many of their friends to join them at the Kopan course that year, including Tom and Kathy Vichta, and Ribush's mother, Beatrice Ribush (1913-2008). Beatrice Ribush was another prominent Buddhist woman in Australia, who later helped establish the FPMT Melbourne Centre Tara House and then became the 'trusty treasurer' of the BSV (Khadro 2015; Vichta 2015; Ribush 2008; Wells 2015).

In 1974, Lama Yeshe arranged for Nicholas Ribush and Khadro to be ordained by His Holiness the Dalai Lama and Ling Rinpoche. They were the first Australians to be ordained in the Tibetan Gelug tradition (Khadro 2015; Vichta 2015). Khadro (2015) described the Lama's first visit to Australia as 'a natural evolution' given that 'so many people were going to the courses' in Kopan. Their first one-month course in Australia was held in Diamond Valley in 1974, and Khadro, Ribush and the Vichtas organised it, setting up a large circus tent for the teachings and an army tent for the kitchen. Lama Yeshe encouraged them to create a Centre, and Ribush, Khadro and the Vichtas owned a large piece of land at Eudlo, which they then gave to the Lamas and FPMT that same year to become Chenrezig Institute (CI). At the end of the first course the Lamas, their students, and Khantipalo, who was staying with the Vichtas at that time, performed a puja ceremony on the property where the current Gompa now stands. CI was the very first of Lama Yeshe's and Lama Zopa's FPMT Centres. Soon after, the FPMT opened Centres in Melbourne, Brisbane, Adelaide, Sydney and Bendigo in the 1970s and 1980s (Croucher 1989; Khadro 2015; Vichta 2015).

Khadro returned to Nepal and the Vichtas and a Canadian nun, Ann McNeil worked together to build and establish CI. Khadro recalled how McNeil, who first managed CI, 'had amazing energy' and 'was quite a character,' as she would lead the meditation sessions as well as drive the four-wheel 
drive and organise the construction work of the Gompa and houses for the Lamas. Some students voluntarily assisted them also. Khadro moved back to CI in 1976 and McNeil departed for Canada. Khadro then lived again in Nepal from 1981 to 1986 before returning to Australia. She then became involved in palliative care, as there was a demand for it emerging in the Australian health system that Buddhist health care practitioners were able to fill. Khadro has been directing Karuna Hospice in Brisbane providing end of life care since 1996 (Khadro 2015).

Venerable Margaret McAndrew, affectionately known as Ani Marg, and a long-time member of CI's community of nuns also first met the Lamas on retreat in Nepal in the early 1970s. She was born and raised in North Eastern Victoria, and became interested in Transcendental Meditation and Zen Buddhism in the 1960s. She travelled to South East Asia in 1973 and upon attending a Kalachakra empowerment course led by His Holiness the Dalai Lama in Bodhgaya was deeply inspired by these teachings. Soon after she participated in a one-month course at Kopan Monastery in Nepal run by Lamas Yeshe and Zopa, and was entirely transformed by this experience. McAndrew (2015) recalled how:

From that moment, I felt that I was connected very strongly with the teachings and from then on there was no question in my mind that I belonged with that tradition and with those teachings ... All my questions were, my problems were suddenly being explained in a way that was really wonderful ... Not just sorting out your problems, not just finding a more steady state of mind, but really going on to higher states of consciousness to enlightenment, life after life, it was so inspiring. (McAndrew 2015)

She continued to travel around Asia but returned to ordain in Kopan in 1975 and then moved back to Australia, living between Tara House in Melbourne and CI before settling in CI to establish a nun's community there with Lama Yeshe's blessing (McAndrew 2015).

Another FPMT nun, Venerable Robina Courtin, has received extensive media coverage in Australia for her supposedly 'unconventional' communication style and continues to draw large audiences of mainly women to her teachings in and beyond Australia (Halafoff 2011). Courtin is another of Lama Yeshe and Lama Zopa's Australian students and a well-known FPMT teacher. She was born in Melbourne in 1944 and raised within a Catholic household. In 1967, she moved to London, living the life of a hippy, as well as being influenced by left-wing politics, black politics, and feminism. Courtin was attracted to Tibetan Buddhism for its 'reflexive and devotional nature,' which [for her] had some similarities to Catholicism. She attended a retreat led by Lamas Yeshe and Zopa at CI in the mid-70s and became committed to Buddhism at that time (Courtin 2015; Halafoff 2011). Following the Buddhist instruction to 'check-up' and not simply to follow with blind faith, Courtin explained how:

... when I checked in my mind, it seemed reasonable. I checked the students, I checked the teachings, I checked them [the Lamas] —it seemed to all, you know it seemed quite valid and I was very kind of impressed by that. On the one side, freaked out about it because the philosophy was so weird but on the other side I knew this was, I felt very confident that it was the path that I wanted. (Courtin 2015)

Soon after, she travelled to Kopan in Nepal for her ordination and became a dedicated FPMT student and staff member, working for Wisdom Publications. In 1994, she moved to the United States and was based in California, where she became the editor of FPMT's Mandala magazine and later founded the Liberation Prison Project (LPP) providing FPMT teachings to prisoners on death-row (Courtin 2015; Halafoff 2011). Although considered to be 'not your average nun,' due to her down-to-earth and direct manner, Courtin 'follows the Bodhisattva's path of altruistic motivation for personal and social change' and practices and teaches traditional Tibetan prayers, rituals, meditation and vows (Halafoff 2011). She is among many notable women who have made a significant contribution to Buddhism in and beyond Australia.

Finally, and as described briefly in the previous section, Elizabeth Bell first joined the BSV in the early 1960s. She later became the President of the BSV and the Chairman of the BFA in the 1970s. 
Bell also began editing Metta in the mid-1970s and the BSV developed strong links with Sri Lankan and Thai traditions and communities at this time (Croucher 1989), which remain to this day. Following the advice of Khantipalo, Bell and the BSV purchased and established Buddhist House in 1975, which hosted talks by many visiting teachers including Khantipalo and Ledermann. She also helped coordinate the Dalai Lama's first visit to Australia (AWAP Australian Women's Archives Project).

Wells (2015) of the BSV, is another long-serving member of the Australian Buddhist community, who had also studied with Lamas Yeshe and Zopa, Hover and Coleman, and who knew Khantipalo and Ledermann. He described Bell and Beatrice Ribush who were for decades at the helm of Buddhism in Victoria with great reverence:

Elizabeth Bell was I think, quite a remarkable person. If you just met her the first time, you might think that she was a quaint little old lady ... [but] if you spoke to her for any length of time, you would realise that she had ... I don't know if she had a scholarly knowledge of the teachings, but she certainly had a very deep knowledge of the teaching... Beatrice was from an eastern European background ... And very proper. Her hair was always immaculate, and the way she dressed was always immaculate. As was Elizabeth, Beatrice just had more of that, you know, European refinement you might call it about her. So they were quite you know, strong and distinct characters in their own way. (Wells 2015)

\section{Conclusions}

While Croucher (1989) history of Buddhism in Australia begins to describe the ultramodern Buddhist Boom period, so much has occurred since the late 1980s that remains to be studied. The BLSA project has begun to address this but much of the content of the oral histories recorded so far also focus on the pre-1990 period. While the stories of many Ango-European Australian, Western female Buddhist teachers and leaders have now been recounted above, in their own voices or in stories of those who knew them well, many more women are yet to be interviewed, including Indigenous and Asian-Australian women, and also Ango-European women from Zen, Vipassana/Insight, and other Tibetan traditions beyond FPMT, whose contribution to Buddhism in Australia is yet to be sufficiently acknowledged.

What we have learned about the many women who first helped to bring Buddhism to Australia and who were instrumental in its establishment, is that many of them had very strong personalities and characters, and many of them came from privileged positions so could therefore be benefactors and purchase land to set up monasteries and centres. While many worked alongside men, they were themselves trailblazers for Buddhism in Australia, and this led to gender equality being a central principle of the Australian Sangha Association.

Some of these women and their supporters were considered to be controversial, including those who advocate for full bhikkhuni ordination in and beyond Australia. This demonstrates that despite an overarching commitment to gender equality among so-called peak or umbrella bodies, it is yet to be universally achieved and remains opposed by more conservative groups globally, including in Australia. The branding of 'unconventional' or 'controversial' is also problematic when applied to some of these Buddhist women, as it is often used when referring to a woman who has a direct manner, is forthright and questions rules and conventions that do not make sense to her, or to her understanding of Buddhism. It implies that an ideal Buddhist woman should be quiet, and compliant, which is simply not compatible with either the reflexive teachings of the Buddha, the critical reflexivity of modern and ultramodern Buddhism, tenets of engaged Buddhism or with Australian Buddhists more generally who have been described as anti-authoritarian (Barker and Rocha 2011; Halafoff 2011).

In addition to being outspoken, strong, independent, and highly capable, many of these Buddhist leaders were drawn to Buddhism for its rational explanations of the nature of mind and reality, that these women said they could not find in other religions or worldviews that they had been brought up with. Many also were drawn into Buddhism through a connection they experienced with their teachers and with the practice of meditation. Some became nuns and some bhikkhuni, 
thereby questioning emphasis on lay practice and secularisation observed in previous studies on Australian Buddhism. All went on to devote their lives to the study and practice of Buddhism, and often to helping others alleviate their suffering, demonstrating a strong sense of social engagement (Spuler 2000; Barker and Rocha 2011). Some of them did so by campaigning for gender equality in Buddhism, both at home and abroad. All of the women interviewed in the BLSA project whilst embodying qualities of modern Buddhism, were simultaneously trained in traditional methods of Buddhism. While many initially participated in more than one tradition or lineage, providing some evidence of hybridity (Baumann 2001), all then chose a lineage to study much more deeply and have stayed firmly rooted in that tradition. At the same time, many have supported fellow Sangha from diverse traditions to establish their Centres and to work on common causes together, often through the ASA. Indeed, the BLSA interviews are full of examples of different communities and notable individuals, be they Western or Asian, assisting one another in the establishment of Buddhism in Australia, showing that the divisions between Asian and Western Buddhists in Australia were and are simply not so distinct as in other Western contexts.

It is for these reasons that women's engagement with Buddhism in Australia, from the 1970s onward, aligns with the principles of ultramodern Buddhism, in which both modern and traditional elements are present, where Asian and Western teachers and students regularly come together, and where a radical reflexivity has driven these women to seek an alternative-in this case Buddhist-framework, to work on themselves and for the benefit of society. Even before the 1970s, women from the Theosophical Society and notable Buddhist community leaders and activists Marie Byles and Natasha Jackson, paved the way for this ultramodern Buddhism. These early pioneers and Buddhist Boom women in Australia turned their reflexive gaze not only on themselves, but on their lifeworld, and on to their Buddhist organisations and worked to improve and reform them, out of both feminist and Buddhist commitments to help all beings to be treated equally and be free from suffering. Those that are still alive today continue to do so in many platforms such as the FABC, the ASA, Sakyadhita and assisting with disaster relief and campaigning for peace, indigenous and refugee rights in and beyond Australia. Many of these women's stories are yet to be recorded and added to the BLSA project. Finally, there is no doubt that these women have and continue to participate in global flows of Buddhists and Buddhism both into and out of Australia, and to and from Asia, New Zealand, Europe and North America, as eminent teachers themselves or as community leaders supporting visiting teachers and diasporic communities.

The BLSA project will continue to record the oral histories of prominent figures, including more women from multiple traditions, and we also hope to be able to conduct further historical research and quantitative studies to better understand how and why Buddhism has adapted to and is growing so successfully in Australia. The more we learn, the more embedded and mature Buddhism reveals itself to be in this vast and diverse country.

Author Contributions: Anna Halafoff and Edwin Ng conceptualised and designed the BLSA study, in consultation with the FABC and the ASA. Ng and Halafoff coordinated the crowdfunding Pozible campaign with assistance from the Deakin-Pozible team. Halafoff and $\mathrm{Ng}$ conducted the BLSA interviews, which were filmed by Freeman Trebilcock. Halafoff, Jayne Garrod and Laura Gobey transcribed and analysed the BLSA interview data referred to in this paper and wrote, revised and edited it together.

Acknowledgments: We would like to thank the FABC, the ASA, all donors to the crowdfunded BLSA project, the Deakin-Pozible team, and all of the BLSA interviewees, and particularly those cited in this paper.

Conflicts of Interest: The authors declare no conflict of interest.

\section{References}

Adam, Enid. 2000. Buddhist Women in Australia. Journal of Global Buddhism 1: 138-43.

AWAP (Australian Women's Archives Project). 2014. Elizabeth Bell. The Encyclopedia of Women and Leadership in Twentieth-Century Australia. Available online: http:/ /www.womenaustralia.info/leaders/biogs / WLE0318b.htm (accessed on 19 April 2018). 
Barker, Michelle, and Cristina Rocha. 2011. Introduction. In Buddhism in Australia: Traditions in Change. Edited by Cristina Rocha and Michelle Barker. New York: Routledge, pp. 1-19.

Barzaghi, Subhana. 2011. The Journey of a Lay Female Zen Teacher: On a Withered Tree a Flower Blooms. In Buddhism in Australia: Traditions in Change. Edited by Cristina Rocha and Michelle Barker. New York: Routledge.

Baumann, Martin. 2001. Global Buddhism: Developmental Periods, Regional Histories, and a New Analytical Perspective. Journal of Global Buddhism 2: 1-43.

Beck, Ulrich. 2006. The Cosmopolitan Vision. Cambridge: Polity Press.

Beckford, James A. 1990. The sociology of religion and social problems. Sociological Analysis 51: 1-14. [CrossRef] BLSA (Buddhist Life Stories of Australia). 2016. Buddhist Life Stories of Australia. Available online: http:// buddhiststoriesaus.net (accessed on 24 March 2018).

Bouma, Gary D., and Jan Brace-Govan. 2000. Gender and Religious Settlement: Families, Hijabs and Identity. Journal of Intercultural Studies 21: 159-75. [CrossRef]

Bouma, Gary D., and Rod Ling. 2005. The Research Process, 5th ed. Oxford: Oxford University Press.

Brahm, Ajahn. 2009. Ajahn Brahm on Why He Was Excommunicated. Sujato's Blog: Buddhism for a Small World: Views and Opinions. Available online: http:/ / sujato.wordpress.com/2009/11/07/ajahn-brahm-on-why-hewas-excommunicated/ (accessed on 22 June 2012).

Brahm, Ajahm. 2015. Interviewed by Anna Halafoff at Bodhinyana Monastery for the ‘Buddhist Life Stories of Australia Project'. August 1. Available online: https://vimeo.com/channels/buddhismaustralia/180364145 (accessed on 24 March 2018).

Casanova, Jose. 1994. Public Religions in the Modern World. Chicago: University of Chicago Press.

Courtin, Robina. 2015. Interviewed by Anna Halafoff at Atisha Centre for the 'Buddhist Life Stories of Australia Project'. July 26. Available online: https:/ / vimeo.com/channels/buddhismaustralia/181022904 (accessed on 24 March 2018).

Croucher, Paul. 1989. Buddhism in Australia: 1848-1988. Kensington: New South Wales University Press.

Gross, Rita M. 2005. Where have we been? Where do we need to go? Women's Studies and Gender in Religion and Feminist Theology. In Gender, Religion and Divesrity. Edited by Ursula King and Tina Beattie. London and New York: Continuum, pp. 17-27.

Habermas, Jurgen. 1981. New Social Movements. Telos 49: 33-37. [CrossRef]

Halafoff, Anna. 2011. Venerable Robina Courtin: An Unconventional Buddhist? In Buddhism in Australia: Traditions in Change. Edited by Cristina Rocha and Michelle Barker. New York: Routledge, pp. 148-52.

Halafoff, Anna, and Praveena Rajkobal. 2015. 'Sakyadhita International: Gender Equity in Ultramodern Buddhism,' Special Issue, Women, Religion and the State. Feminist Theology 23: 111-27. [CrossRef]

Halafoff, Anna, and Emma Tomalin. 2017. Bhikkhuni Ordination and Digital Activism. Paper presented at the 15th Sakyadhita International Conference on Buddhist Women, Contemporary Buddhist Women: Contemplation, Cultural Exchange e \& Social Action, Hong Kong, China, 22-28 June.

Halafoff, Anna, Fitzpatrick Ruth, and Lam Kim. 2012. Buddhism in Australia: An Emerging Field of Study. Journal of Global Buddhism 13: 9-25.

Khadro, Yeshe. 2015. Interviewed by Anna Halafoff at Karuna Centre for the 'Buddhist Life Stories of Australia Project'. January 27. Available online: https://vimeo.com/channels/buddhismaustralia/180312982 (accessed on 24 March 2018).

Lopez, Donald. 2002. A Modern Buddhist Bible, Essential Readings from East and West. Boston: Beacon Press.

Lyall, Graeme. 2014. Interviewed by Anna Halafoff at Amitabha Buddhist Association for the 'Buddhist Life Stories of Australia Project'. December 28. Available online: https:/ /vimeo.com/channels/buddhismaustralia/ 175107758 (accessed on 24 March 2018).

McAndrew, Margaret. 2015. Interview with Margaret McAndrew Conducted by Anna Halafoff at Chenrezig Institute for the 'Buddhist Life Stories of Australia Project'. January 30. Available online: https: / vimeo. com/channels/buddhismaustralia/178012942 (accessed on 24 March 2018).

McAra, Sally, Metcalf Franz, and Halafoff Anna. Forthcoming. Buddhism in Australia, Canada, New Zealand and the USA. In The Wiley-Blackwell Companion to South and Southeast Asian Buddhism. Edited by Michael Zimmermann. Oxford: Blackwell Publishing, vol. 1.

McMahan, David. 2011. Buddhist modernism. In Buddhism in the Modern World. Edited by David McMahan. Hoboken: Routledge, pp. 160-75. 
$\mathrm{Ng}$, Edwin, and Anna Halafoff. Forthcoming. Buddhist Life Stories of Australia: Crowdfunded Research, Faithful Scholarship, and Inquiries on Making Refuge. Journal of Global Buddhism, under review.

Nirodha, Ayya. 2015. Interviewed by Anna Halafoff at Santi Monastery for the 'Buddhist Life Stories of Australia Project'. January 12. Available online: https://vimeo.com/channels/buddhismaustralia/181033252 (accessed on 24 March 2018).

Quli, Natalie. 2008. Multiple Buddhist Modernisms: Jnana in Convert Theravarda. Pacific World 10: 225-49.

Rajsilaporn, Phra. 2015. Interviewed by Anna Halafoff at Santi Monastery for the 'Buddhist Life Stories of Australia Project'. January 13. Available online: https://vimeo.com/channels/buddhismaustralia/174354890 (accessed on 24 March 2018).

Ribush, Nicholas. 2008. Beatrice Ribush (2013-2008) Lama Yeshe Wisdom Archive. Available online: https: / / www.lamayeshe.com/article/beatrice-ribush-1913-2008 (accessed on 19 April 2018).

Rocha, Cristina, and Michelle Barker, eds. 2011. Buddhism in Australia: Traditions in Change. New York: Routledge.

Sakyadhita. n.d. 1st Sakyadhita International Conference, Sakyadhita. Available online: http:/ /sakyadhita.org/ conferences/1st-si-con.html (accessed on 24 March 2018).

Santi Forest Monastery. 2016a. Bhikkhuni Upasampada Confirmed and Completed by Ajahn Brahm and the Bhikkhu Sangha. Available online: http://santifm.org/santi/2016/09/22/bhikkhuni-upasampadaconfirmed-and-completed-by-ajahn-brahm-and-the-bhikkhu-sangha/ (accessed on 24 March 2018).

Santi Forest Monastery. 2016b. First Bhikkhunī Upasampada for Santi and for NSW. Santi Forest Monastery. Available online: http:/ / santifm.org/santi/2016/09/07 / first-bhikkhuni-upasampada-for-santi-and-fornsw / (accessed on 24 March 2018).

Spuler, Michelle. 2000. Characteristics of Buddhism in Australia. Journal of Contemporary Religion 15: 29-44. [CrossRef] Squire, Corinne, Andrews Molly, and Tamboukou Maria. 2008. Introduction: What is narrative research? In Doing Narrative Research. Edited by Molly Andrews, Corinne Squire and Maria Tamboukou. London: Sage, pp. 1-21.

Sujato, Bhante. 2009. How Australia's first Theravada Bhikkhuni Ordination Happened. Sujato's Blog: Buddhism for a Small World: Views and Opinions. Available online: http://sujato.wordpress.com/2009/10/31/howaustralia\%e2\%80\%99s-first-theravada-bhikkhuni-ordination-happened/ (accessed on 22 June 2012).

Sujato, Bhante. 2015. Interviewed by Anna Halafoff at Bodhinyana Monastery for the ‘Buddhist Life Stories of Australia Project'. August 2. Available online: https://vimeo.com/channels/buddhismaustralia/180312984 (accessed on 24 March 2018).

Sunim, Chi Kwang. 2015. Interview with Chi Kwang Sunim conducted by Anna Halafoff at the Seon Centre for the 'Buddhist Life Stories of Australia Project'. January 5. Available online: https:/ vimeo.com/channels/ buddhismaustralia/122072208 (accessed on 24 March 2018).

Tsomo, Karma Lekshe. 2009. Global Exchange: Women in the Transmission and Transformation of Buddhism. In Trans Buddhism: Transmission, Translation, Transformation. Edited by Nalini Bhushan, Jay L. Garfield and Abraham Zablocki. Amherst: University of Massachusetts Press, pp. 151-66.

Vichta, Kathy. 2015. Interviewed by Anna Halafoff at Chenrezig Institute for the 'Buddhist Life Stories of Australia Project'. January 30. Available online: https://vimeo.com/channels/buddhismaustralia/175627538 (accessed on 24 March 2018).

Wells, Michael. 2015. Interviewed by Anna Halafoff at Buddhist Society of Victoria for the 'Buddhist Life Stories of Australia Project'. January 8. Available online: https:/ /vimeo.com/channels/buddhismaustralia/121230397 (accessed on 24 March 2018).

Willaime, Jean-Paul. 2006. Religion in Ultramodernity. In Theorising Religion: Classical and Contemporary Debates. Edited by Beckford James A. and Walliss John. Aldershot: Ashgate, pp. 77-89.

(C) 2018 by the authors. Licensee MDPI, Basel, Switzerland. This article is an open access article distributed under the terms and conditions of the Creative Commons Attribution (CC BY) license (http:/ / creativecommons.org/licenses/by/4.0/). 